\title{
前庭神経切断術例の日常生活障害度
}

久保武・山川 純至・井関 裕義

\section{Results of Handicap Inventory in Vestibular Neurectomy Cases}

\author{
Takeshi Kubo, Zyunshi Yamakawa, Hiroyoshi Iseki \\ Department of Otolaryngology, Osaka University Medical School
}

Between 1990 and 1995, vestibular neurectomy was performed in 14 patients with Ménière disease or other peripheral vestibular disorders. Acute symptoms after neurectomy subsided within two weeks. Long term-results of vestibular neurectomy were evaluated from results of a questionnaire regarding handicaps in daily life. Responses were collected from 12 patients more than 2 years after the surgery. Physical or functional restrictions were reported by 8 to $16 \%$ of the patients. Psychological handicap was also reported by 8 to $16 \%$ of the patients. Questions regarding auditory function revealed the same tendency. However, 11 of 12 subjects indicated satisfaction with the results of vestibular neurectomy. Although this procedure is considered the most effective surgery for vertigo attack, a small percentage of patients felt some restrictions in daily life.

Key words: Ménière disease, Vestibular neurectomy, Restrictions in life, Hearing, Handicap inventory

我々は, 難治性のメニエール病にたいし外科的 治療として Silverstein の方法に準じた後 S 状静 脈洞前庭神経切断術1)を扣こなってきた。この手 術法は，過去にも報告したと扔り，めまい発作の 予防, 聴力保存といった点で優れており，また手 術侵襲扣よび術後の合併症も少ないものであ る2)3)

今回, 術後 2 年以上経過した例に対し，日常生 活における平衡障害の有無, 難聴による生活の障 害度についてアンケート調查を扣こない，その結 果を短期間の観察結果と比較して検討した。

\section{対象と方法}

当施設にて平成元年より約 5 年間で後 $\mathrm{S}$ 状静 脈洞前庭神経切断術を拍こなった症例は計14名で あり，その内訳を表 1 に示した。年龄の平均は 48.6 才, 罹病期間の平均は 4.8 年, 術前の会話域
平均聴力は $54.1 \mathrm{~dB}$ であった。疾患として, メ ニエール病が 12 例で, この内 4 例は内リンパ霓開 放術あるいはストレプトマイシン治療にてめまい が再発した症例である。他に遅発性内リンパ水腫 および迷路炎がそれぞれ1名ずつ含まれている。 この14例のらち術後 2 年以上経過した12例につい て，以下に述べるアンケート調查を抗こなった。 めをい・平衡障害に関するアンケート調查票に

表 1 前庭神経切断術例の内訳

\begin{tabular}{|c|c|}
\hline 別 & 男 10 ：女 4 \\
\hline 年齢 & $48.6 才 \quad(29-65 才)$ \\
\hline 罹病期間 & 4.8 年 $\quad(1.4-11$ 年) \\
\hline 術前德力 & $54.1 \mathrm{~dB}^{+} \quad$ (S D $\left.19.8 \mathrm{~dB}\right)$ \\
\hline 術後僡力 & $56.2 \mathrm{~dB}^{+} \quad$ (S D $\left.20.1 \mathrm{~dB}\right)$ \\
\hline
\end{tabular}


は，西池らの作成した日常生活障害度調査票を用 いだ)。これは Jacobson and Newman の作成し た Dizziness Handicap Inventory (DHI) ${ }^{5)}$ を改 変したものである。

難聴にたいするアンケート調査票は，Ventry と Weinstein ${ }^{6)}$, Weinstein と Ventry ${ }^{7)}$ が老人の 難聴調查のために作成した聴覚障害質問用紙を用 いた。

また，術後急性期の前庭代償過程は，めまい。 平衡障害に関する自覚的訴兄, 自発眼振の ENG 記録，重心動摇検査により評価した。

\section{結 果}

1) 術後成績

表 2 亿計14例の術後成績を示した。患側内耳に 起因するめまい発作は全例で認められておらず, めまいの制御率は100\%であった。14例のうち 2 例では, 強度の耳鳴に加光難聴の程度も強かった ため聴神経も切断したので, 残りの12例で聴力保

\section{表 2 前庭神経切断術の成績}

\begin{tabular}{|c|c|c|c|c|}
\hline \multicolumn{3}{|c|}{ めまいの制御 } & \multicolumn{2}{|c|}{$14 / 14$} \\
\hline \multirow[t]{4}{*}{ 聴 } & 力 $^{*}$ & & & \\
\hline & 保 & 存 & $11 / 12$ & $(91.7 \%)$ \\
\hline & 悪 & 化 & $1 / 12$ & $(8.3 \%)$ \\
\hline & 切 & 断 & $2 / 14$ & $(14.3 \%)$ \\
\hline \multirow[t]{3}{*}{ 耳 } & 嘄 & & & \\
\hline & 軽 & 滅 & $11 / 14$ & $(78.6 \%)$ \\
\hline & 不 & 変 & $3 / 14$ & $(21.4 \%)$ \\
\hline
\end{tabular}

*2 例では婹神経も切断した
存の検討をおこなった。その結果，12例のうち11 例で会話域平均聴力の変化は $10 \mathrm{~dB}$ 以内にとど まり，聴力の保存率は91.7\%であった。また，耳 鳴についても10点法にて 7 点以下を改善とした場 合78.6\%の例で軽減がみられた。

2) 自発眼振扣よび身体動摇からみた前庭代償 術後，自発性めまいが $2-3$ 日，頭を動かした 時に自覚する誘発性めまいは約 1 週間続いたが， その後は自力歩行, 階段の年降も可能となった。 就労している例では, 術後 3 週間で社会復帰が可 能となった。

他覚的には, 明所での自発眼振は平均 10 日間で 消失, 暗所での自発眼振は術後約 20 日で小さくな り，50/秒以下となったが，これが完全に消失 する迄には数か月といら長期間を要した。重心動 摇の記録では，開眼下の起立では 5 日目，閉眼下 の起立では7 日目の記録で手術前の値に戻り，前 述の平衡障害の回復との一致がみられた8)。

3) アンケート結果からみた術後の日常生活障 害度

14 例の手術例のらち 2 年以上経過した 12 例のア ンケート結果を図 1 - 3 に示した。本来のアン ケートでは答えは,「強い」「かなり」,「少し」, 「時々」，「なし」の 5 段階で評価するが，本研究 では集計に際し，「少し」と「時々」を一つにし て 4 段階とした。

日常生活に损いて，めむい・ふらつきを自覚す るかどうかといら身体的 (physical) 制約に関す るアンケート 2 問の結果を図 1 亿示した。振り向

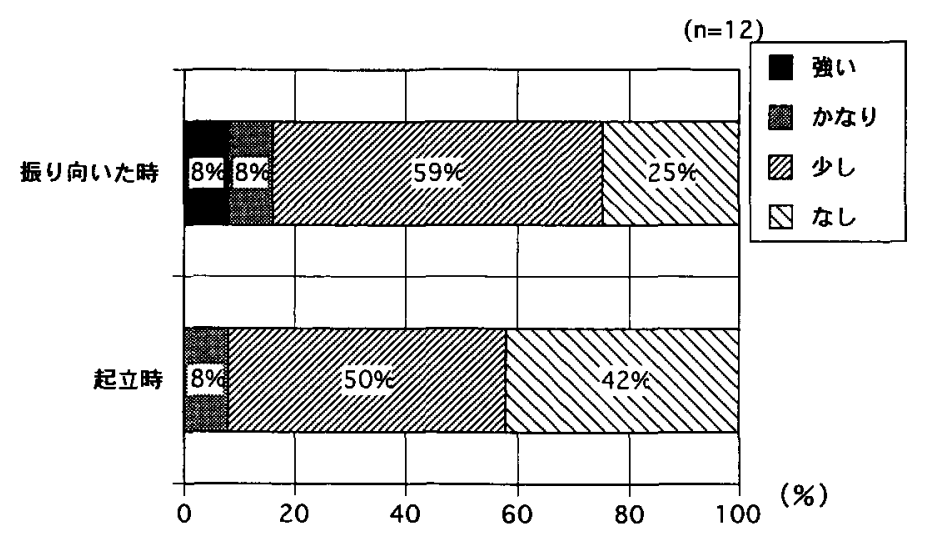

図 1 急速頭位変換時の浮動感

振り向いた時, 起立時に感じる浮動感を 4 段階に評価した。 
いた時，起立時に浮動感を強くあるいはかなり感 じると答えたのは，8-16\%であり，大多数ではな し，あるいは少しといった回答が得られた。

日常生活に括ける行動面 (functional) での制 約について7問の調查を抗こったが，このらち 3 問を選び図 2 に示した。狭い所，暗所，階段の 下降時に非常に困難を感じる，あるいはかなり感 じると答えた例も図 1 の場合と同様 8-16\%であ った。

感情面 (emotional) での障害については 4 問 あったが，このうち2問を選び図 3-B，Cに示し た。家族・友人とのつきあいの上で困る，物事に 集中できないと答えたのは $8 \%$ だあり，残りの例 では少し，あるいは全く感じてないという答えが
得られた。他方，めいいふらつきのためかなり 不安を感じたと答えたのは，17\%にみられ，身体 面, 行動面での障害が心理面にも反映されている ことがらかがえた。

最後に，生活全般の状態で，めまいるららつき によって困っているかどらかを設問した。1例 (9.1\%) で非常に困っているという答えが得られ た以外は，全く困らない(50\%)，少し困る(41.7 \%)といら結果であった（図 3-A）。めまい発作 はなくなったが，日常生活に掠いて軽度の障害を 自覚する例があることがわかった。

4）アンケート結果からみた難聴による障害度 聴覚に関しては, 前述したごとく高率に聴力保 存が可能であったが, 手術側の難聴が術後に改善

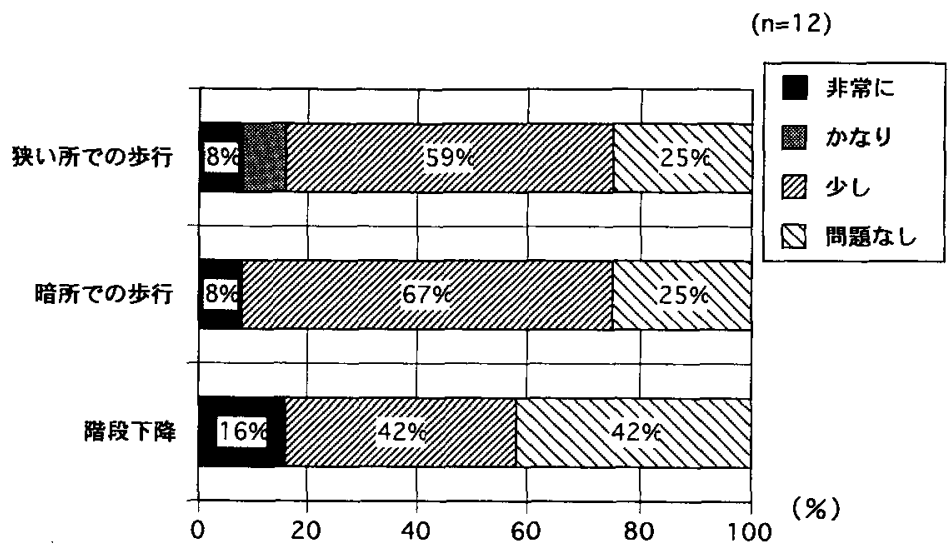

图 2 歩行・階段昇降での障害度

狭い所での歩行, 暗所での歩行，階段昇降時に自覚する浮動感を 4 段階に評価した。

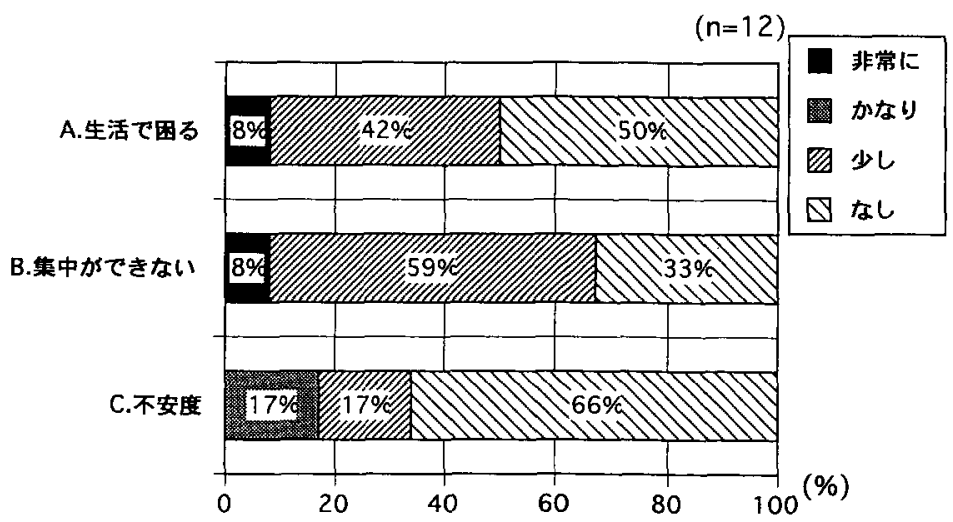

図 3 日常生活での心理的障害度

日常生活での心理的障害，集中ができにくい，不安を持つといった 3 項目について 4 段階に評洒した。 
するわけではないので, 難㯖によるハンディキャ ップは手術前と同椂に残ると想定される。全ての 症例の術後患側聴力は平均 $56.2 \mathrm{~dB}(\mathrm{SD} 20.1 \mathrm{~dB})$ であり, 健側聴力は平均 $18 \mathrm{~dB}(13.3 \mathrm{~dB})$ であっ た。

難聴による生活上のハンディキャップをアン ケートにより調べた結果を図4 亿示す。難聴に関 するアンケートは, はい, 時々, いい光, の3つ の回答から選ぶようになっている67)。さささやさ 声の聞き取りは，半数以上の例で困難と答えて扣 り，テレビ・ラジオの聞き取りは25\%で困難であ った。他方，難聴により常時生活の制限あるいは

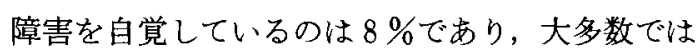
なし，あるいは時々といった回答が得られた。

\section{考察}

前庭神経切断術は，内耳でめまいが括こっても それを脳に伝達する部位で遮断することを目的に 扣こなわれるもので，理論的にもめまい発作の予 防といら点では最も效果的な方法である。しか し，この手術では一側の前庭機能を除去してしま らため, 術後にめまい.平衡失調がしばらく続 く。この後中权神経系でおこる前庭代償により， 一定期間が過ぎればめまい.平衡失調は減少す る9)。術直後に怙こるめまい. 平衡障害は約 2 週 間で軽快し, 他覚的にも, 重心動摇・自発眼振の 記録により術啳の前庭代償の過程を観察しえた。 他方, 長期経過例へのアンヶート調查では, 急速 な頭位変換時の浮動感といった身体面での障害を
8-16\%の例で訴えた。暗所・狭い所・階段下降 時に平衡障害を自覚するという機能面での障害も 同様に 8-16\%の例にみられた。心理的な面での 不満も，同率にみられた。この 8-16\%の例でみ られた不満足な結果の理由として,

i) 1 例 $(1 / 12,8 \%)$ において, 手術当時は正 常聴力であった反対側で, 術後10か月目にメ二 エール病が発症し, 両側メニエール病となった。

ii） 65 才で手術を执こなった1例が，平衡障害， 難聴による障害を強く訴えた。

ことが関与していた。両側メニエール病の発症は 予期できないものであるが，術前にこの可能性も 考慮にいれて説明することが必要である。また， 高齢者では術後の前庭代償が遅延, あるいは完成 しないこともあり手術時年令を考慮することが肺 要であることを示哱する結果であった。しかし， 生活全般に括ける障害度の質問では，1例の両側 メニエール病を除き，打扮むね満足している結果 が得られた。術前に仕事をもっていた8例では， 全員社会生活への復帰も果たされて和り，適応の 選択を厳格におこなえば満足すべき手術法である と考えられる。

聴力の保存に関しては，AAO-HNS (1985) に 準じた純音聴力の術前後の比較によって，91.7\% の例で聴力の保存が可能であった。しかし, 難聴 に関するアンケート調查では，ハンディキャップ を8-16\%の例で訴えた。一側（11例）あるいは 両側の難聴（1 例）に上る日常生活の障害が，こ

$(n=12)$

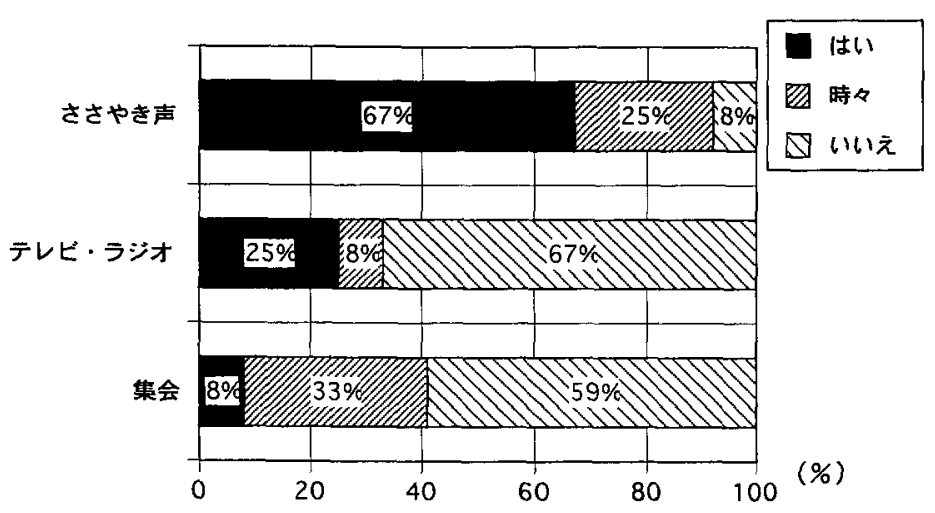

図 4 聞き取りの障害

ささやき声，テレビ・ラジオの聴取，集会での聞き取りについて 3 段階で評価した。 
の程度の率で訴兄られるものと理解される。 まとめ

1）難治性メニエール病など14例にたいし前庭 神経切断術を扣こない, 術直後の観察および長期 経過を調べた。

2 ) 術直後の観察では, めまい.平衡障害は約 2 週間で軽快することがわかった。また，聴力の 保存率も91.3\%の高率で抗こな充た。

3） 2 年以上を経過した例にたいし, 日常生活 に拉ける制約の有無についてアンケート調査を扰 こなった。その結果，8-16\%の例で頭位变換時に 浮動感・平衡障害があると訴えた。をた，難聴に よる日常生活に括けるハンディキャップを 8-16 \%の例で訴えた。

4）生活全般にわたる障害度の調查では, 両側 メニエール病の 1 例 $(9.1 \%)$ を除き，少し困る （41.7\%）あるいは全く困らない（50\%）という 結果であり, 術後の社会復帰の状況と合わせて考 えると満足すべき結果であった。

本研究は平成 6-7 年度厚生省特定疾患前庭機 能異常調査研究班による研究費の支給を受けたも のである。

文献

1) Silverstein H, Norrell $H$ : Retrolabyrinthine surgery: A direct approach to the cerebellopontine angle. Otolaryngol Head Neck Surg 88: 462-469, 1980
2）久保武，白石孝之，西村將人，他：めまい ・耳鳴に対する第 VIII 神経切断術. Equilibrium Res 50: 209-214, 1991

3）久保 武：めまいの外科治療.耳鼻臨床 87 : 1613-1621, 1994

4 ）西池季隆, 武田憲昭, 肥塚 泉, 他: めまい 患者の日常生活障害度。日耳鼻 98: 31-40, 1995

5 ) Jacobson GP, Newman CW: The development of the dizziness handicap inventory. Arch Otolaryngol Head Neck Surg 116: 424427, 1990

6 ) Ventry I, Weinstein B: The hearing handicap onventry for the elderly. Ear Hear 3: 128134, 1982

7) Weinstein B, Ventry I: The assessment of hearing handicap in the elderly. Hearing Aide J1: 35: 17-20, 1982

8 ) Kubo T, Doi K: Assessment of auditory and vestibular functions following vestibular neurectomy. Acta Otolaryngol 115: 149-153, 1995

9 ) 久保 武, 土井勝美 : 前庭神経切断術之前庭 代償. ブレインサイェンス 4: 133-140, 1993

$\left(\begin{array}{l}\text { 原稿到着: 平成 } 7 \text { 年 } 8 \text { 月 } 23 \text { 日 } \\ \text { 別刷請求先 : 久保 武 } \\ \text { † } 565 \text { 大阪府吹田市山田丘 } 2-2 \\ \text { 大阪大学医学部耳鼻咽嗼科学教室 }\end{array}\right)$

